\title{
THE MOST IMPORTANT QUALITY CRITERIA OF SOME HOME-GROWN BLACK-CURRANT VARIETIES
}

\author{
III. Aroma number, organoleptic evaluation, and degree of ripeness
}

TAINA KuUSI

\begin{abstract}
The State Institute for Technical Research, Laboratory for Food Research and Technology, Otaniemi
\end{abstract}

Received May 30, 1966

A report is given here of the further quality characterization of some homegrown black-currant varieties. In this series, and with the same material, earlier findings were given in Part I (8), as concerns the ascorbic acid content, and in Part II (9), the dry matter, pectin, acid content, colour, and formol value of the berries.

In this section of the study, Part III, the methods applied are explained separately for each property.

I A r o m a n u m ber. For the assay of aroma, there was used the method of BRUNNER \& SENN (2) which gives the amount of volatile reducing substances. In addition, in some series the method of SENN (12) was also applied; in this, treatment with mercuric oxide $(\mathrm{HgO})$ is used for elimination of the carbonyl compounds, it being assumed that ethanol alone then remains as volatile reducing component. In earlier investigations of the author (6), it was noted that in black-currant aroma, the values after $\mathrm{HgO}$ treatment were often higher than if this treatment had been omitted, contrary to expectations. It was thought that this result was attributable to the salt effect of $\mathrm{HgO}$, which raises the volatility of the aroma compounds (6). Since then Koch \& Schiller (5) have proposed another possible explanation of similar effects, that the esters in the apple aroma examined were partly hydrolysed by $\mathrm{HgO}$, and that the resultant alcohols brought about a rise in the aroma numbers obtained.

The assa s were made with frozen or fresh material. In those cases where it seemed prob ble that secondary changes had taken place in the fresh samples, the values of the frozen samples were used in the comparison. The amount taken for the assay : as usually $10-15 \mathrm{~g}$, sometimes only $5 \mathrm{~g}$. In checking experiments, it 
Table 1. Averages of aroma number assays of black-currant varieties in 1962-1964, and the general averages.

$\begin{array}{lcccc} & 1962 & 1963 & 1964 & \text { Average } \\ \text { Westwick Choice } & 149 & - & - & 149 \\ \text { Roodknop } & 98 & - & - & 98 \\ \text { Gerby } & 95 & - & 44 & 70 \\ \text { Wellington XXX } & 88 & 74 & 29 & 64 \\ \text { Brödtorp } & 87 & 50 & 35 & 57 \\ \text { Aström } & - & 56 & - & 56 \\ \text { Boskoop } & 50 & - & - & 50 \\ \text { Black of Lepaa } & 64 & 41 & 36 & 47 \\ \text { Silvergieter } & 21 & 55 & - & 38 \\ \text { Goliath } & 36 & 44 & 9 & 30 \\ \text { Wellington X } & 29 & 28 & 17 & 25 \\ \text { Janslunda } & 5 & 35 & 30 & 23\end{array}$

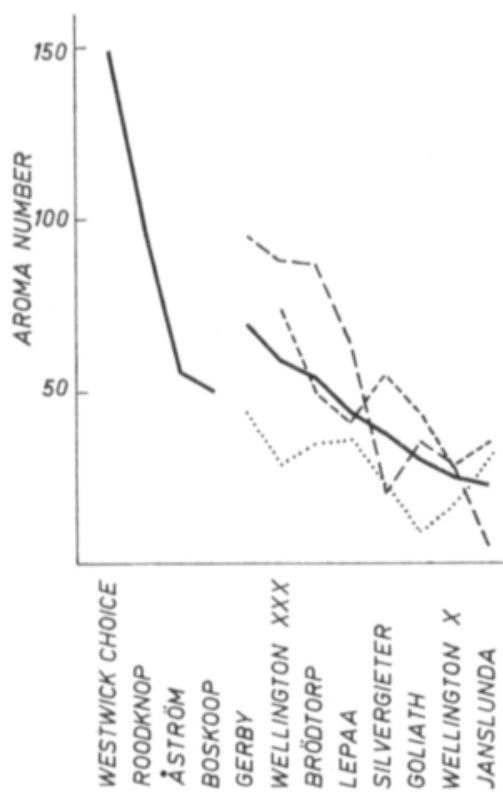

Fig. 1. A comparison of the aroma number of black-currant varieties in the different years investigated and the averages.

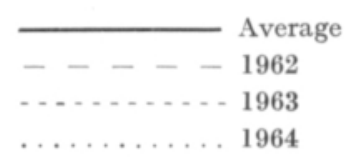

was found that although small samples, under the conditions used, gave somewhat higher values than did large ones, as the aroma compounds are distilled more quantitatively from small samples, this difference is in practice insignificant.

Table 1 presents the results for the 3 years as averages of the varieties, along with the general averages in diminishing order.

Fig. 1 illustrates the results. When the different years are compared, it is noted that the values are lowest in 1964, and are in general higher than the average for both 1962 and 1963. As it seems that the formation of ethanol, and other secondary changes which occur during transport, easily increase the aroma number, this result may be attributable to the unfavourable transport conditions in some cases in 1962 , and to the high summer temperature in 1963 , which may have caused un- 
usually great changes. It should be remarked that in 1962 the aroma number assays were performed with both fresh and frozen material; the values given above are from the frozen samples, which were considered more reliable. The corresponding values obtained from the fresh samples were considerably higher, and it is assumed that secondary changes had taken place here. In addition, with the material of this year, aroma number assays were also made after $\mathrm{HgO}$ treatment, but here the samples had been frozen. This treatment is assumed to remove carbonyl compounds and to give, in the main, the ethanol content. It was found that the values thus arrived at were in general higher than the ordinary aroma numbers. The interpretation may be that in black-currant there are no carbonyl compounds present which are measurable by this means, although as mentioned earlier, other interpretations might be applicable.

Comparison of the different varieties evidences the existence of considerable differences. Nevertheless, as the aroma number is evidently strongly influenced by various factors, particularly the degree of ripeness and condition, it is not certain that the differences between the varieties are significant. To check this point, a calculation was made of the extent to which the difference between the varieties Wellington XXX (No. 4 in the sequence) and Wellington X (correspondingly No. 11) is significant. This calculation gives the following result:

\begin{tabular}{|c|c|c|c|c|c|}
\hline & Average & St.D. & $\mathrm{n}$ & $\begin{array}{l}\text { Limits } \\
\text { calculated }\end{array}$ & $\begin{array}{l}\text { zariation } \\
\text { observed }\end{array}$ \\
\hline Wellington $\mathrm{XXX}$ & 59 & \pm 41 & 10 & $18-100$ & $9-140$ \\
\hline Wellington $\mathrm{X}$ & 25 & \pm 7 & 3 & $18-32$ & $17-29$ \\
\hline $\begin{array}{l}\text { Degree of freedom: } \\
\text { P }\end{array}$ & $\begin{array}{r}11 \\
>80\end{array}$ & & & & \\
\hline
\end{tabular}

As was to be expected, the significance of the varietal differences is not very high, as other factors induce great variability.

A comparison of the results in respect of the different years, on the basis of the yearly averages and the limits of variation, is made below:

\begin{tabular}{|c|c|c|c|c|c|}
\hline & \multirow[t]{2}{*}{ fresh } & \multicolumn{2}{|c|}{$\begin{array}{l}1962 \\
\text { frozen }\end{array}$} & \multirow[t]{2}{*}{1963} & \multirow[t]{2}{*}{1964} \\
\hline & & directly & $\mathrm{HgO}$ treated & & \\
\hline $\mathbf{n}$ & 13 & 16 & 16 & 16 & 17 \\
\hline Average & 115 & 71 & 84 & 53 & 31 \\
\hline $\begin{array}{l}\text { Limits of } \\
\text { variation }\end{array}$ & $35-196$ & $5-149$ & $33-156$ & $17-86$ & $9-75$ \\
\hline
\end{tabular}

It seems that the unfavourable transport conditions in 1962 definitely increased the aroma number to a greater degree than high summer temperature of 1963 . It is also possible, however, that a high summer temperature may augment the loss of easily volatile aroma compounds.

The effect of the "northernness" of the growing place is considered in the following comparison, in which the order of the localities starts from the south: 


$\begin{array}{lrcr} & \mathrm{n} & \text { Average } & \text { Limits of va } \\ \text { Piikkiö } & 21 & 32 & 5-55 \\ \text { Pälkäne } & 5 & 28 & 9-72 \\ \text { Laukaa } & 7 & 42 & 11-84 \\ \text { Ylistaro } & 4 & 77 & 44-117 \\ \text { Maaninka } & 10 & 89 & 40-149 \\ \text { Rovaniemi } & 2 & 101 & 75-127\end{array}$

There apparently exists a general, increasing trend towards the north, which may be connected partially with the effect of prolonged transport, but not decisively.

By way of general comment on the findings, it may be mentioned that the determination of the aroma number was originally developed for measurement of the strength of the aroma in aroma distillates and concentrates (cf. 2). It has but seldom been applied for direct measurement of the aroma of fruits and berries as such, although in instances where the amount of volatile reducing substances is sufficient, as is the case with black-currant, such application is possible when the approximate evaluation of the aroma content is required. Very little comparative information is to be found in literature; apart from the aroma numbers earlier arrived at for black-currant material here (cf. 6: 142, 69; also 7: 68.5; these values are from frozen material), only the values given by CHARLEY (3) seem to have been published. Here, the moxidation numbers» in fresh juice varied between 129 and 390; in the latter case it is assumed that slight fermentation had taken place. These values obtained with British berries are rather higher than the values derived here. This may be because berries used for juice production should for preference be somewhat overripe, as this facilitates the pressing operation; this again induces a rise in the aroma number. Moreover, the varieties in Great Britain may also differ from those grown most in Finland; Charley's article did not specify the variety.

When this method was adopted for aroma measurement tests, its limitations were realized (cf. 6). Subsequently, Косн \& Schiller (5) are included among those who have criticized the method, considering it unsuitable for evaluation of the amount of aroma in their study concerned with apples. Consequently, it was thought that comparison of the results of this method, and the corresponding results obtained with gas chromatography, might provide further information on the usefulness of the aroma number assay, which has in any case the advantage of being relatively simple, and easy of performance. This comparison will be made later in conjunction with evaluation of the results of the gas chromatographic aroma study.

I I. Organoleptic evaluat i on. Me t ho d s. For these experiments berries, stored frozen, were thawed and evaluated. The following properties were taken as criteria: colour or appearance, smell, and taste; the points given were $0-2$, $0-4$, and $0-10$ respectively; thus the maximum total of points is theoretically 16 (method of $\mathrm{KocH}$, cf. 1). In evaluation of the appearance, the samples were submitted as such for judgment after thawing; in cases where secondary changes had taken place, which would have involved differences in the wholeness exercising too great an influence on the results, the samples were homogenized with mixer; 
in one year, an additional dilution with water in the proportion 1: 1 was made. For the evaluation of smell and taste, the thawed berries were presented either as such, or homogenized as explained above. As these samples had a rather strong taste, flavourless wafers were given as an aid to neutralization. At most, 6 samples were

Table 2. Smell averages of points during the 3 years, and general averages.

$\begin{array}{llllc} & 1962 & 1963 & 1964 & \text { Average } \\ \text { Åström } & & 3.25 & & 3.25 \\ \text { Goliath } & 3.5 & 3.10 & 2.80 & 3.15 \\ \text { Boskoop } & 3.4 & & & 3.4 \\ \text { Silvergieter } & 3.6 & 2.88 & & 3.12 \\ \text { Wellington X } & 3.5 & 2.75 & 2.60 & 2.95 \\ \text { Brödtorp } & 3.28 & 3.32 & 2.58 & 3.03 \\ \text { Janslunda } & 3.44 & 2.92 & 2.85 & 3.03 \\ \text { Gerby } & 3.08 & & 2.00 & 2.54 \\ \text { Wellington XXX } & 3.04 & 2.93 & 2.49 & 2.71 \\ \text { Black of Lepaa } & 3.25 & 2.70 & 2.58 & 2.74 \\ \text { Westwick Choice } & 2.83 & & & 2.83 \\ \text { Roodknop } & 2.58 & & & 2.58\end{array}$

Table 3. Taste averages of points during the 3 years, and general averages.

$\begin{array}{lllll} & 1962 & 1963 & 1964 & \text { Average } \\ \text { Åström } & & 7.92 & & 7.92 \\ \text { Goliath } & 9.25 & 7.24 & 8.10 & 7.96 \\ \text { Boskoop } & 7.5 & & & 7.5 \\ \text { Silvergieter } & 7.8 & 7.36 & & 7.51 \\ \text { Wellington X } & 7.63 & 6.83 & 8.40 & 7.62 \\ \text { Brödtorp } & 8.31 & 7.67 & 7.23 & 7.71 \\ \text { Janslunda } & 7.75 & 6.90 & 6.60 & 7.04 \\ \text { Gerby } & 8.0 & & 7.50 & 7.75 \\ \text { Wellington XXX } & 7.63 & 6.83 & 8.40 & 7.62 \\ \text { Black of Lepaa } & 7.89 & 6.78 & 6.71 & 7.0 \\ \text { Westwick Choice } & 5.75 & & & 5.75 \\ \text { Roodknop } & 5.5 & & & 5.5\end{array}$

Table 4. Averages of points totals during the 3 years, and general averages.

$\begin{array}{lcccc} & 1962 & 1963 & 1964 & \text { Average } \\ \text { Åström } & & 13.17 & & 13.17 \\ \text { Goliath } & 14.75 & 12.34 & 12.50 & 12.98 \\ \text { Boskoop } & 12.85 & & & 12.85 \\ \text { Silvergieter } & 13.1 & 12.24 & & 12.53 \\ \text { Wellington X } & 12.88 & 11.25 & 12.80 & 12.31 \\ \text { Brödtorp } & 13.34 & 12.83 & 10.98 & 12.30 \\ \text { Janslunda } & 13.19 & 11.62 & 11.30 & 11.94 \\ \text { Gerby } & 12.66 & & 10.56 & 11.61 \\ \text { Wellington XXX } & 12.17 & 11.38 & 10.51 & 11.13 \\ \text { Black of Lepaa } & 13.0 & 11.06 & 10.13 & 11.08 \\ \text { Westwick Choice } & 10.21 & & & 10.21 \\ \text { Roodknop } & 9.96 & & & 9.96\end{array}$


submitted on the same occasion. The number of judges varied between 4 and 6 . As a rule, samples from the same locality were evaluated simultaneously; if the number of samples was too large for this, evaluation was carried out in two lots, with an

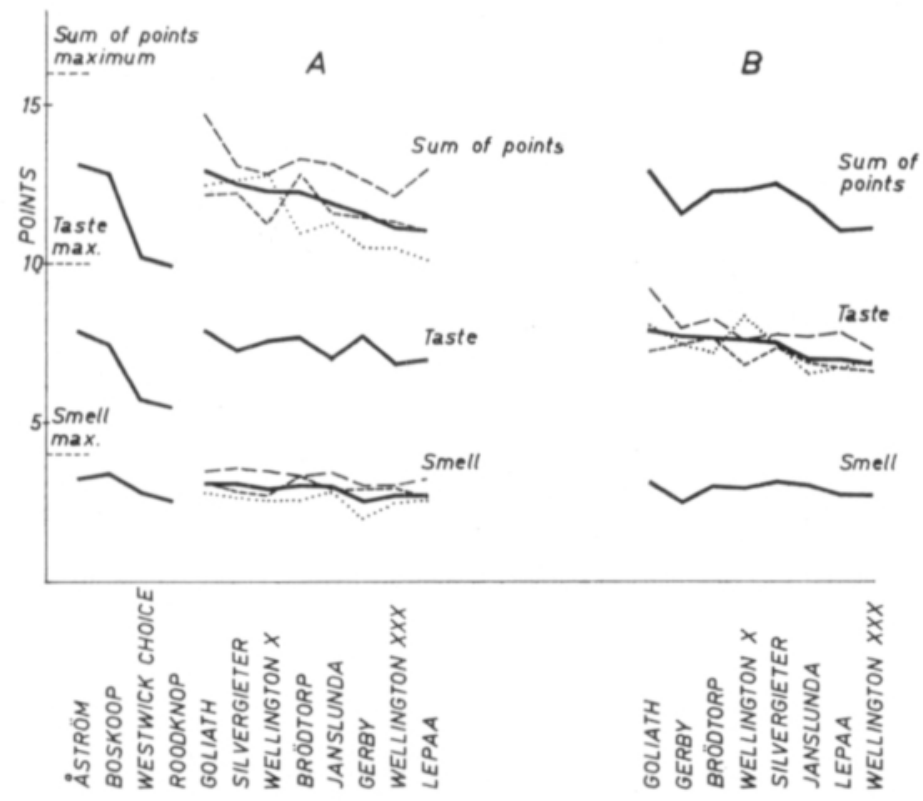

Fig. 2. Smell and taste points, and the points totals in organoleptic evaluation of the black-currant varieties in the different years under study, in comparison with the corresponding averages.
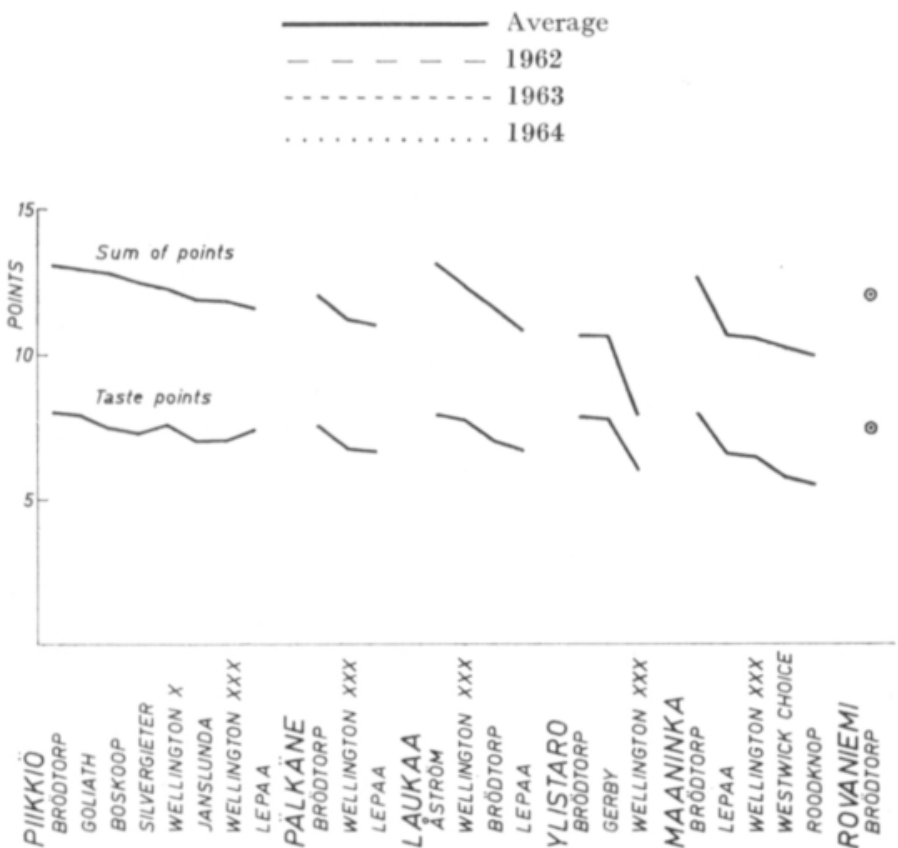

Fig. 3. Taste points and points totals as averages of the varieties in the 3 years, indicating the sequences of the varieties in the different growing localities. 
additional cross testing. In some series, sugar was added to the samples to be evaluated, as the judges found it difficult to taste such sour samples. It was realized that the order of the samples remained unchanged, irrespective of whether sugar was added or not. However, in general preference was given to testing without the addition of sugar, with a view to keeping the samples in their original state as far as was practicable.

$\mathrm{Results}$. The results indicated that as far as appearance was concerned the values differed so slightly that there is no point in giving the values. As regards the other properties, the results relating to smell, taste, and the points total are presented in the tables below, where the averages of the different varieties in the 3 years in question, along with the general averages, have been compiled in the order of decreasing points totals.

The findings are illustrated in Figs. 2 and 3. In Fig. 2, the varieties of which only one sample was studied are on the left. In the middle $(\mathrm{A})$, the varieties are given in decreasing order of points totals, on the right (B) in decreasing order of taste points. It is observable from the last-mentioned part of the figure that if examination is made of the decreasing order of taste points, the course of the points totals shows a somewhat divergent line, but that the lines of smell points, and the points totals take a very similar course. Again, as concerns the different years, the 1962 values are regularly higher than the average, but those of 1963 and 1964 in general lower than this. As the differences between the varieties are rather slight, the order may to some extent vary in the different years, but the general features are relatively consistent. Fig. 3 presents the results with respect to taste points and points totals as average of the 3 years for each locality separately. This comparison indicates a general trend, that in most cases the points of Brödtorp are among the highest.

In view of the relatively slight differences, it was considered necessary to check the extent of their statistical significance. For this purpose, the varieties Goliath, No. 2 in the sequence, and Black of Lepaa, No. 10, were chosen. The calculation gave the following result:

Goliath

Black of Lepaa

Degree of freedom

$\mathrm{P}=>99 \%$

Goliath

Black of Lepaa

Degree of freedom

$\mathrm{P}=>90 \%$

\section{Points total}

Average St.D. n $\begin{gathered}\text { Limits of variation } \\ \text { calculated }\end{gathered}$

$12.98 \pm 1.22 \quad 4 \quad 11.76-14.20 \quad 11.87-14.75$

$11.08 \pm 1.47 \quad 9 \quad 9.61-12.55 \quad 9.85-14.70$

11

II Taste Points

Average St.D. $\mathrm{n}$ Limits of variation

calculated observed

$7.96 \pm 0.96 \quad 4 \quad 7.00-8.92 \quad 7.08-9.25$

$7.00 \pm 0.86 \quad 9 \quad 6.14-7.86 \quad 7.54-9.20$ 
It is evident from the calculation that the difference in the points totals is very significant, and quite considerable in the taste points as well. As redargs the smell points, a similar calculation would not be very reliable, since the evaluation of smell is subject to more uncertainty than the other organoleptic properties; such a calculation has accordingly been omitted. The differences between the other varieties examined are generally less prominent than that considered in the calculation above.

In literature, no more than relatively little exact information has been found for comparative purposes. The varieties studied here have been investigated, particularly in Denmark and Sweden (e.g. 4, 10, and 11), and the organoleptic properties of the berries have also been evaluated; nevertheless, in most cases this has been one part of the descriptions of the varietal properties, without precise comparison of the varieties. GROvEn (4) reports on a comparison of the marketing value of some of these varieties, using as criterion the appearance, which includes the size of the berries, evenness of the crop, wholeness, and colour. In this comparison, the best varieties were Boskoop, Brödtorp and Wellington XXX (9/10 points), followed by Silvergieter and Westwick Choice (8/10), and last of all Roodknop (7/10). Thus the trend in the main bears similarity to that discerned in the present results, although the evaluations are not strictly comparable. In general, it may be assumed on the basis of the descriptions of the varieties that the best organoleptic quality was connected with such factors as mildness, sweet taste, thin skin, and large size and juiciness of the berries.

I I I. Degree of ripeness. As regards the degree of ripeness of the berries investigated with the material from the years 1963 and 1964, consideration needs to be limited, as those berries judged unripe were eliminated from the samples for analysis, and accordingly the effect exercised by the degree of ripeness on the results obtained must be rather small. However, as the question of the degree of ripeness is of considerable interest, some relevant points are examined below.

The degree of ripeness was evaluated by separation from the samples of those berries which were clearly unripe, and estimation of their percentage by weighing. The unripe berries were adjudged as those green or red in colour. However, in some instances the berries, although reddish-black, had been softened during transport; in such cases, the berries were considered ripe. Table 5 below gives the yearly averages and general averages of the varieties studied as percentages of the unripe berries; there is a further inclusion of the limits of variation for the different varieties, along with calculations of the general average for the two years, and the corresponding range of variation.

The Table 5 shows that in some cases, particularly in respect of Black of Lepaa and Wellington XXX, the variations were appreciable.

Since ripening depends on the temperature, it is natural to assume that the degree of ripeness of the berries bore a correlation to the effective temperature totals until the day of picking: the higher the temperature total is, the less the number of unripe berries. This assumption was established as being fulfilled: the expected correlation was observable both in use of the values for the different samples and in use of the general averages of the varieties in the years concerned. 
Table 5. Averages of the percentages of unripe berries during the 2 years, along with the general averages and range of variation of the varieties and during the years.

$\begin{array}{lccrr} & 1963 & 1964 & \begin{array}{r}\text { General } \\ \text { average }\end{array} & \begin{array}{c}\text { Range of } \\ \text { variation }\end{array} \\ \text { Black of Lepaa } & 16.4 & 13.4 & 15.6 & 3.2-34.2 \\ \text { Wellington XXX } & 3.8 & 20.1 & 13.5 & 2.2-43.2 \\ \text { Gerby } & & 10.9 & 10.9 & \\ \text { Åström } & 9.6 & & 9.6 & \\ \text { Brödtorp } & 4.7 & 8.6 & 6.8 & 0.9-14.6 \\ \text { Janslunda } & 6.2 & 6.8 & 6.5 & 6.2-6.8 \\ \text { Wellington X } & 9.0 & 3.4 & 6.2 & 3.4-9.0 \\ \text { Goliath } & 6.6 & 1.3 & 4.0 & 1.3-6.6 \\ \text { Silvergieter } & 2.7 & & 2.7 & \\ & & & & \\ \text { Yearly average } & 7.2 & 12.7 & & \\ \text { Yearly variation range } & 0.9-11.8 & 1.3-43.2 & & \end{array}$

The effect of variety induces variability, and consequently some varieties such as Black of Lepaa, and particularly Wellington XXX, were in this material less ripe than average, whereas Brödtorp was riper than average. Fig. 4 illustrates the correlation.

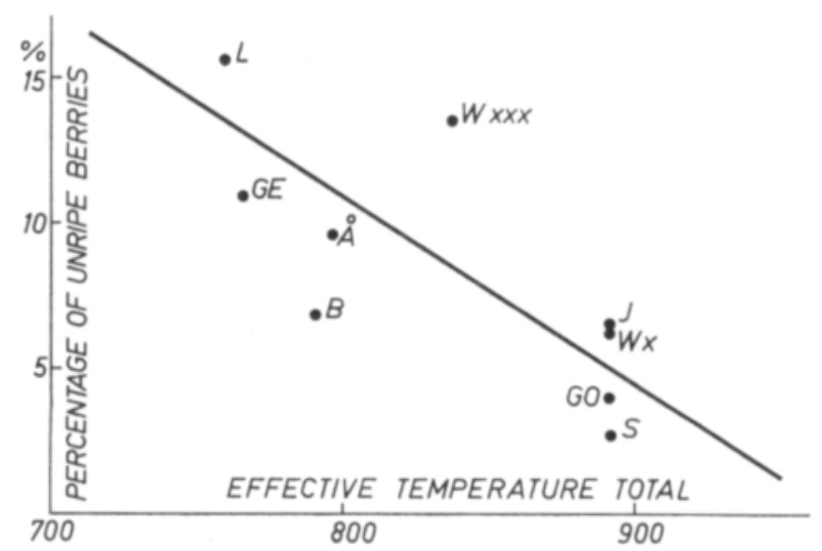

Fig. 4. Correlation between the averages of the degree of ripeness of the black-currant varieties and the corresponding effective temperature totals. $\mathrm{B}=$ Brödtorp; $\mathrm{GE}=\mathrm{Gerby}$; $\mathrm{GO}=\mathrm{Goliath}$; $\mathrm{J}=$ Janslunda; $\mathrm{L}=$ Black of Lepaa; $\mathrm{S}=$ Silvergieter; WX $=$ Wellington $\mathrm{X} ; \mathrm{WXXX}=$ Wellington XXX; $\AA=$ Aström

Literature contains rather scanty information on estimation of the degree of ripeness. However, with respect to studies made in CHARLEY's laboratory (cf. 13), FORE has suggested that black-currants picked for chemical analysis, as well as for juice production, should be taken at such a phase that $80-85$ per cent of the berries 
are fully black. If picking is done before this, the aroma has not developed fully, and again, if the picking is effected later ascorbic acid losses may occur, and the berries may be crushed during transport. If this suggestion is accepted, it seems evident that the after-ripening which occurs during transport has also been taken into account, and thus the transport time need not be very short. Evaluation of the degree of ripeness in the present experiments was carried out after transport, and of course the berries were thus riper than as suggested by CHARLEY.

It seems evident that degree of ripeness may influence many of the properties of the berries, such as the amount of ascorbic acid, pectin, colour, aroma, organoleptic properties, and so on. In the present experiments, however, the unripe berries were eliminated from the samples analysed, the aim being reduction of the effect of the degree of ripeness to as great an extent as possible. The influence of the degree of ripeness remains only in that, notwithstanding selection of the berries, the remaining berries might feasibly have been less ripe in cases where the percentage of unripe berries was high. Thus a slight effect might have been present in any case. In 1962, although the degree of ripeness was not measured, it was noted that Roodknop and Westwick Choice were somewhat unripe; this had probably increased the ascorbic acid value, but had diminished the colour strength, and lowered the taste points in the organoleptic evaluation. Correspondingly, consideration was given to whether in 1963 and 1964 a correlation was discernible between the degree of ripeness, and the colour strength or taste points. Some correlation thus became apparent between the colour strength and the degree of ripeness, such that the colour was stronger in riper berries; however, the variability was appreciable. Åström and Black of Lepaa, for instance, showed a rather strong colour despite the large number of unripe berries, and in Goliath the colour was weaker than the average, notwithstanding the advanced degree of ripeness. In the taste points, the differences were small and the correlation was uncertain; in general, the riper samples were accorded higher taste points, but here the differences in the degree of ripeness were probably lessened not only by elimination of the clearly unripe berries, but also by the after-ripening occurring during the storage phase.

\section{$S u m m$ ary}

A study has been made of the quality properties of 12 home-grown varieties of black-currant. Samples were obtained from six localities over a period of three years. The properties studied consisted of the aroma number, the organoleptic evaluation, and the degree of ripeness.

As regards aroma number, great variations were noted between the samples. The influence of variety was rather slight. In general, the aroma numbers were higher when the summer was cool and the growing locality more to the north, probably by reason of the losses of volatile reducing substances at higher temperatures. The utility of the aroma number in characterization of quality seems limited in scope. 
Smell and taste were taken as the main criteria in the organoleptic evaluation. The differences between the varieties were not very great, but in any event a relatively consistent sequence was discovered. Consideration is given to some factors which influence organoleptic properties.

The degree of ripeness of the samples, and the effect of this factor on the quality properties, were studied. The degree of ripeness displays a correlation with the corresponding effective temperature totals. Here, the effect of the ripeness factor on the results was only slight, as unripe berries were removed from the samples before analysis. However, some effect may have remained, to some degree influencing the colour strength, but the organoleptic properties to a lesser degree.

Acknowledgement. My thanks are due to the Department of Horticulture and to the experimental stations which provided the material.

\section{REFERENCES}

(1) Beythien, A. \& Diemair, W. 1957. Laboratoriumsbuch für den Lebensmittelchemiker. 7. Aufl. Dresden \& Leipzig.

(2) Brunner, H \& Senn, G. 1957. Die quantitative Kontrolle des Aromaentzuges aus Fruchtsäften in Aromarückgewinnungsanlagen. Schweiz. Zschr. f. Obst- u. Weinbau 66, 25: 587-591.

(3) Charley, V. L. S. \& Robbins, R. H. 1962. Some observations on the production of volatile substances from blackcurrant juice. Symposium Fruchtarome Bern. Berichte der wissenschaftlich-technischen Kommission der Internat. Fruchtsaftunion, pp. 137-149.

(4) Groven, I. 1962. Sortsforsøg med solbaer. Tidskr. for Planteavl 65: 411-434.

(5) Косн, J. \& Schiller, H. 1964. Beitrag zur Kenntnis des Apfelaromas. Z. Lebensm. Untersuch. u. Forsch. 125, 5: $364-368$.

(6) KuUsı, T. 1962. Versuche über die Technologie der Produkte aus schwarzen Johannisbeeren und die Erhaltung von deren Aroma. Flüssiges Obst 29, 10: 14-17.

(7) - -1964 . The effect of freezing-drying, cloudiness and concentration on the keeping quality of various blackcurrant products. J. Sci. Agr. Soc. Finland 36: 161-180.

(8) - 1965. The most important quality criteria of some homěgrown black-currant varieties. I. Ascorbic acid. Ibid. 37: 264-281.

(9) - - 1965. The most important quality criteria of some homěgrown black-currant varieties. II. Dry matter, pectin, acid content, colour and formol value. Ibid. 37: 282-304.

(10) LARsSon, G. 1959. Norrländska sortförsök med svarta vinbär 1944-1958. Stat. trädg. förs. Medd. 122: $1-30$.

(11) NiLsson, F. 1959. Nya sorter av bärväxter. Statens trädgårdsförsöks särtryck serie $\mathrm{Nr} 95-$ Jord-Gröda-Djur 1959: 115-120.

(12) Senn, G. 1960. Die Alkoholbestimmung in Fruchtsäften und Aromakonzentraten. Fruchtsaftindustrie $5,5: 165-173$.

(13) Tressler, D. K. \& Joslyn, M. A. 1961. Fruit and vegetable juice processing technology. Westport, Connecticut, Pp. 453-457: Ascorbic acid in blackcurrant fruits and juices, by V.L.S. CharLey. 
S ELOST U S:

\section{MUSTAHERUKAN TÄRKEIMMISTÅ LAATUOMINAISUUKSISTA ERÄILLÅ KOTIMAASSA VILJELLYILLÄ LAJIKKEILLA}

III. Aromiluku, organoleptinen arvostelu ja kypsyysaste

Taina KuUSi

Valtion teknillinen tutkimuslaitos, Elintarviketeollisuuslaboratorio, Otaniemi

Kotimaassa viljeltyjen mustaherukkalajikkeiden laatuominaisuuksien selvittämiseksi suoritettiin vertaileva tutkimus 12 eri lajikkeella. Näytteitä saatiin 6 paikkakunnalta, 3 vuoden aikana. Tutkimuksen kohteina olivat aromiluku, makuarvostelu ja marjojen kypsyysaste.

Aromilukuun nähden näytteet poikkesivat melkoisesti toisistaan. Lajikkeen vaikutus aromilukuun oli melko vähäinen. Aromiluku oli yleensä korkeampi kun kesä oli viileämpi ja kasvatuspaikka pohjoisempi, mikä perustunee siihen, että korkeammassa lämpötilassa pelkistävissä haihtuvissa aineissa tapahtuu häviötä. Aromiluvun käyttökelpoisuus laadun karakterisoimisessa lienee melko rajoitettu.

Aistinvaraisessa arvostelussa olivat pääasiallisina arvosteluperusteina haju ja maku. Lajikkeiden välillä ei ollut suuria eroja, mutta paremmuusjärjestys muodostui kuitenkin melko yhdenmukaiseksi. Muutamia organoleptisiin ominaisuuksiin vaikuttavia tekijöitä on tarkasteltu.

Näytteiden kypsyysastetta ja tämän tekijän vaikutusta tuloksiin on myös tutkittu. Kypsyysaste on selvässä korrelaatiossa näytteiden poimintahetkeen saakka laskettuihin lämpösummiin. Kypsyysasteen vaikutus laatua karakterisoivien analyysien tuloksiin on ollut melko vähäinen, koska näytteistä on ennen analyysejä poistettu selvästi raa'at marjat. Vähäistä vaikutusta lienee kuitenkin esiintynyt; tämä on jonkin verran vaikuttanut mm. värinvoimakkuuteen, mutta vähemmän organoleptisiin ominaisuuksiin. 